\title{
A CASE OF TETANUS DEVELOPED AFTER EAR OPERATION
}

By

\author{
Kuniya FUJIWARA, Yuzuru MASUdA AND Nobuzo NAGAO \\ From the Department of Oto-Rhino-Laryngology, Okayama University \\ Medical School (Director: Prof. S. Takahara)
}

Toru TAKEUCHI

From the Department of Pediatrics, Okayama University

Medical School (Director: Prof. E. Hamamoto)

A report is made on a rare case of 12 year-old boy in which tetanus developed after ear operation.

Inspite of preoperative meticulous disinfection of the operation fields, symptoms suspective of tetanus such as trismus, rigidity of neck muscles appeared 12 days after radical operation of the ear.

Assuming the case to be tetanus, antitoxic serum was given and the patient showed rapid recovery.

\section{中耳根本手術に合併した破傷風の1例}

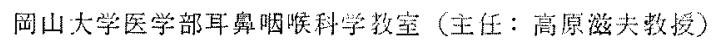

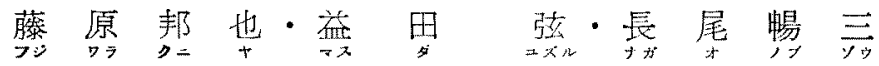

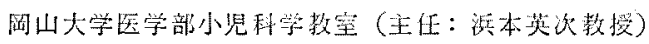

竹唯喜

\section{緒容}

耳科領域に预いては，往来，破傷風に関する記載梳 であるが，殊に耳手術微に合併した症例は，本邦では，

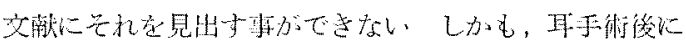

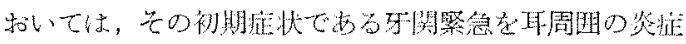

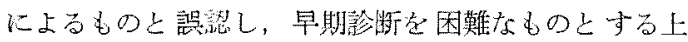

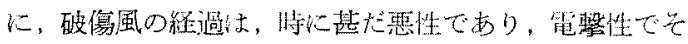

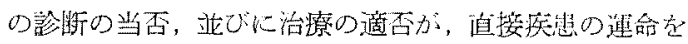

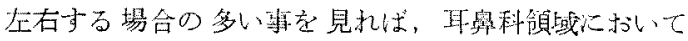

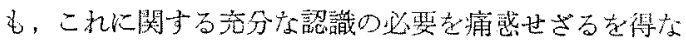
い. 我々は今回, 右中耳根本手術捘, 12 日目以開口韵

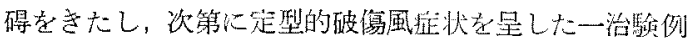

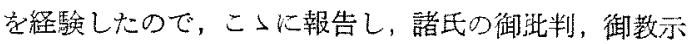
索仰き度い上思う。

$$
\text { 症例 }
$$

患者荻日某。12才男昌。

初䛦昭和 36 年3月24日

\section{主訴 右難悖}

既应歴 2 才の時，麻疹に羅患した他，著变なく，ッ ヘルタリン反応は，昭和 36 年 4 月陽転，外傷を受けた 释嶈なし。

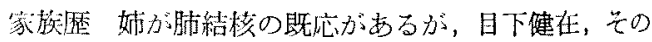
他特棓す心さ牙なし。

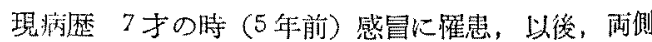
耳漏をきたすよらになり、某耳奥科医の治療を受け，間 もなく左耳は治癒したが，右耳は低然してて耳漏止ら ず，時に耳痛をきたすよらになつた。的 2 力年保存的治 潦家継続した結果かなり症状は軽快し，時々耳漏を見る 程度となつたが，先の中，次第に在耳閉塞感，難㯖、時に 「ッーン」と云ら耳鳴があらわれてきた。しかし，自覚 的に耳痛, 眸最, 頭重, 発熱, 自声強聴等はなかつだ.

現症

1) 全身所見：体格栄諡中等度，発育正常，顔貌正， 胸腹部に著变を認めず 
2) 局所々見：右鼓摸には，前上部に真洙腯を認め， 下半分に辺渌性穿孔あり, 穿孔縁さ肥厚し, 鼓室には広 く真侏連上皮が伸び悪卓の強い粘稠な黄色膿计が貯留し ていた，耳管の通気度は良好で廔孔症状なし，左鼓膜は 前下 $1 / 4$ 亿洀痕を認め，や>内陌している他，異常を認 めなかつた，鼻腔，咽頭腔にも特記すべき变化はなか つた.

\section{真珠腫上皮}
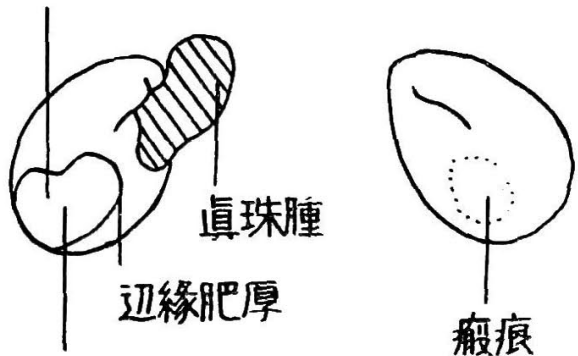

般痕

\section{穿孔膿十}

OkayamāUniversity ${ }_{\mathbf{1}}^{-}$Medical ${ }_{\mathbf{A}}^{\mathbf{T}}$ School

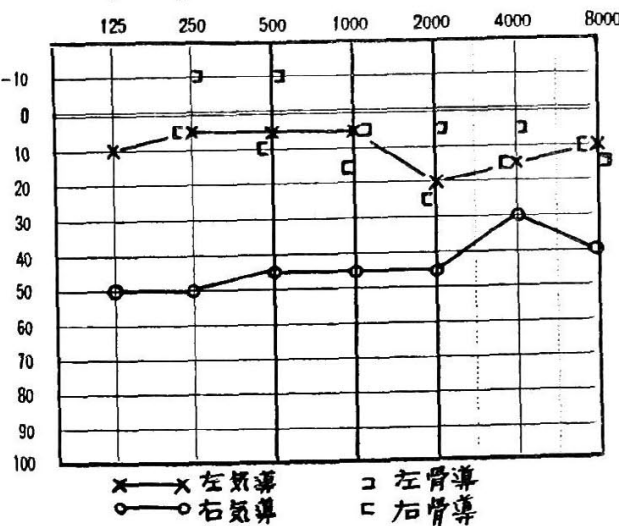

検査所見：聴力検査では，左は正常，右は会話音域 平均, 気導 45 デシペル，骨導 17 デシペルの聴力損失あ り，耳部レントゲン写真撮影の結果は，左耳正常，右耳 は，蜂㸗発育不良にしてアントルムの部に真珠腫による と思われる院影欠損を認めた．血液像は正常であつた。

飧断：右上鼓室化膿症（真珠尰）

\section{治療及び経過}

手術前日，患耳及び大腿内側を $10 \%$ オスパン溶液， $2 \%$ 酒精マーキユロ，70\%アルコールで各 3 回つ〉，撖 重に消毒後,減菌ガーゼにて清瑇部位を覆い, 繃带を施し た. 女，手術当日は，術前に再び同様の部の消毒を施行
した上で non-rebreathing method による気管内麻酔 の下に耳内切開による右中耳根本手術を实施した。手術 所見としては，上鼓室，洞，下鼓室には，真珠腫が充満

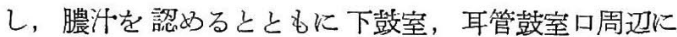
病的肉莱があり．桘骨と砧骨以癒着，鐙骨は消失してい た. 真珠腫，病的肉芽，耳小骨を除去した上で，消毒し た大腿部より採つた全層遊離皮弁を創面に植皮し，その 上に，マイシリン粉末と滅菌小ガーゼを入れて術を終兄 た. 手術時, 顎関節, 䁘膜等を損傷するような事は全く なかつた。術後 1 週間は，毎日油性ペニシリン 30 万単 位注射，シノミン内服を継続，眩晴，耳痛,頭痛，顏面麻 痺, 発熱等なく, 術後7 日目に耳内ガーゼを除去, その 後，毎朝，傷処置をして経過順調であつた．ところが術 後 10 日目より耳漏が多くなり，朝タ 2 回の耳処置を要 するようになると同時に, 侯凝感, 顔面紅潮, 発汗等を 訴えるようになつた。次いで術後12日目よりは更に開 口棉碍 $(2 \mathrm{~cm})$ をきたしたので，先す゚手術による顋関節 炎，あるいは顎関節周目炎症，あるい惼桃腺炎， ワ ンサン氏口峽炎, 顎下腺炎, 耳下腺炎等の㐼発を疑つた が，発熱，顎関節痛，茵痛，顔面腫脹等なく，咽頭，顎 下腺，耳下腺にも異常なく，又，クボステク氏現象，項 部强值をも認めなかつた。しかしこの中で開口障㥂が西 ると云らことから一応，顎関節部の炎症を考光て，ハイ シリン40万单位の経口投与夌開始した。 ところが䍿朝 (術後 13 日目) になつて, 意識は明膫, 頭痛, 嘔吐等は なかつたが，上肢の痤㴚系，項部強值のあることに気付い

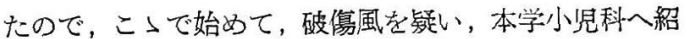
介した。

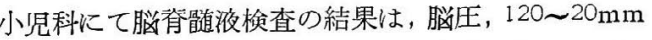
水柱 (5cc 排液) 細胞数は2/3で「破傷風の矛い」の下 に, 破傷風抗毒素血清 12000 単位を上腕, 简笳に注射,

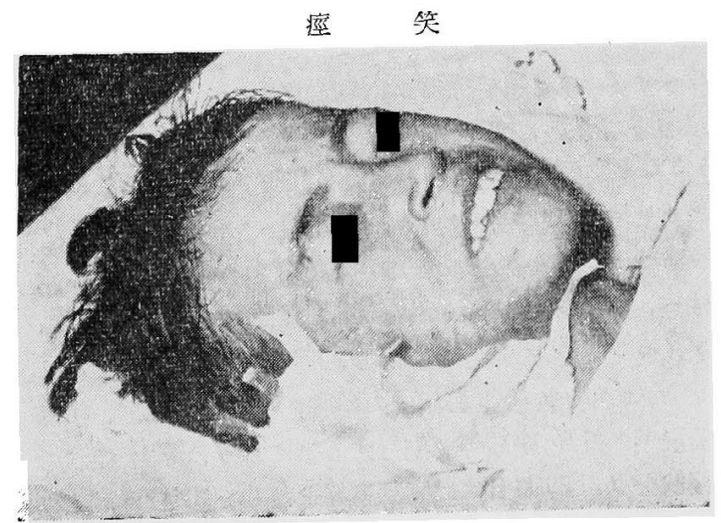


コントミン $12.5 \mathrm{mg}$, 水性ペニシリン 80 万単位注射, アイロタインン $800 \mathrm{mg}$ を 投与し, 病室には暗幕を用い, 可及的外 界よりの刺激を避け安静を保たしめるよ らにした。術後 14 日目には, 項部强直 強く, 頸背部痛, 頻脈, 痤笑を誌めた。

右耳漏の単染色，グラム染色を試久た が破傷風菌は証明できなかつた，夺，蟆 下障碍はなかつたが, 開口障碍は次第に 強々，流動食の他は食碪摂取不可能とな つた. 耳は，植皮升を除去後，毎日朝夕 2 回 $3 \%$ オキシドールで耳内消毒, 清拭 しマイシリン扮末を入れ術創にはガーゼ 1 枚を覆い、開放創とした。

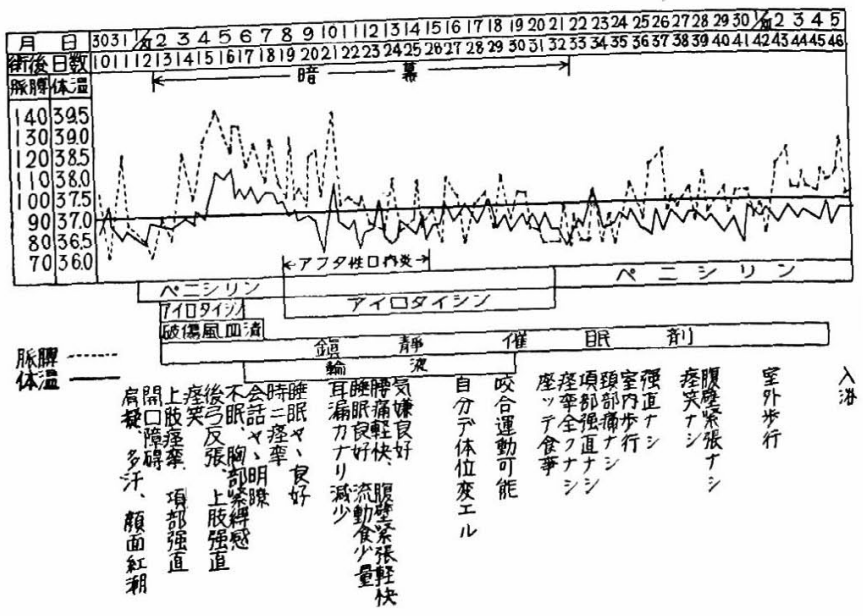

身全痤 㯐

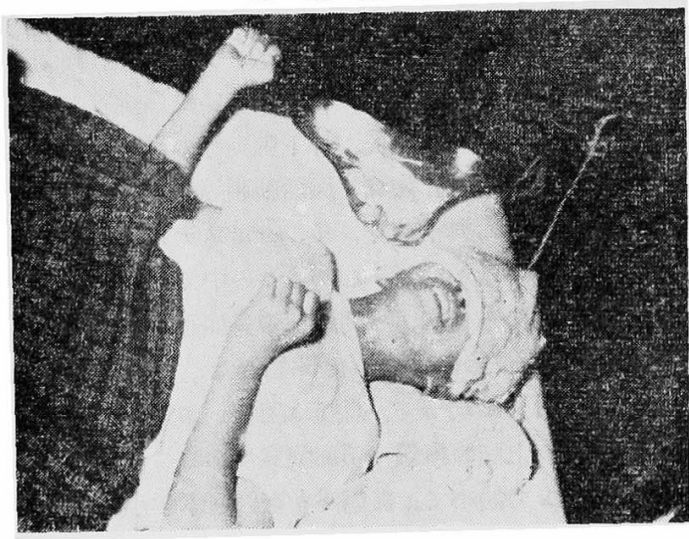

術後 15 日目, 更に腹痛, 腰痛点訴え次第に疼痛至伴 ら四肢の强㨁性痤䟕を反復し，これに後弓反張をきたす 事も屡々となり，そのため，終夜不眠の状態を続けるよ らになつたので，小览科に転科した、耳漏を豚肝寒天に 注加培荃したが破傷風菌は証明できなからた。5 日間， $37 \sim 38^{\circ} \mathrm{C}$ の発熱が持続したが次第に下熱，一般の破稘 風治療汇徒小, 術後13日目上り術後17日目迄, 総計 84000 単位の破傷風抗毒素血清䘮, 又, 痤戀発作, 疼痛 に対しては $5 \%$ 抱水クロラール注腸, フェノバール， プロン A 等を注射, 術後15 日目より18 日目迄は, 水 性ペニシリン 80 万単位注射, 19 日目より31日目迄は, アイロタイシン $1000 \mathrm{mg}$ 内服, 31 日日以捘はペニシリ ン $\mathrm{V}$ カルシウム 60 万単位の内服, その間，適宜，鎮静 催眠凪の投与, 輸液等を施行与る事により，漸次，症状の 軽快を見，22 日目には睡眠良好となり，31 日目には坐

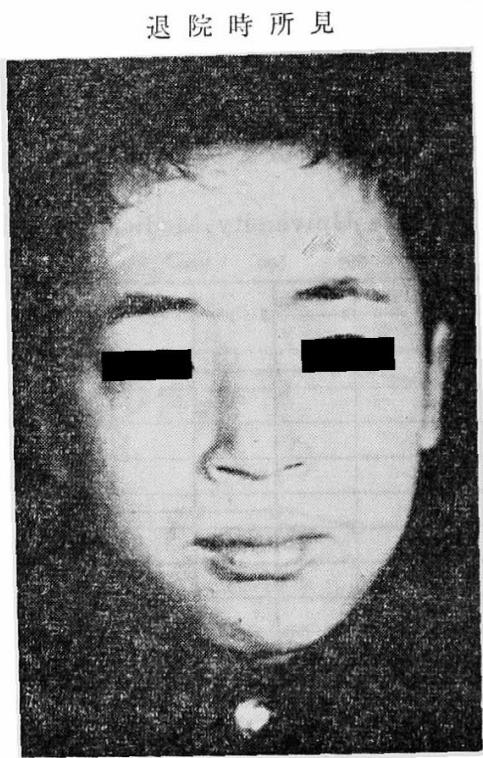

つて食事し, 痤彎全くなく，暗幕を除去，35日日には， 室内步行開始，38日目には痤笑もとれ，48 日目には耳 処置のため，耳鼻科入再入院，先の後は，耳内創面子上 皮化，乾燥してきたので，術後55 日目に全治退院させ た.

な括，本症経過山，19日目よりアフタ性口内炎を併発 したか゚，アクロマイシントローチ．ビスラーゼ注射等の 治療により約 1 週間で治瘉した.

\section{総括及び考按}

本症例に括いては, 既述の如く, 創傷部よりの鏡検及 び培盖によつては，破傷風菌を確認できなからたか゚、特 


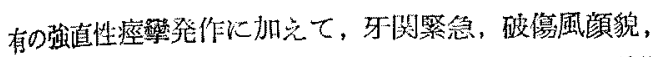
後弡張をきたしたので，本例が破傷風であるとの診断 の正否については述べる必要はないと思う

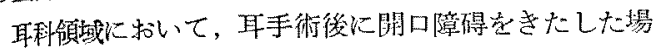

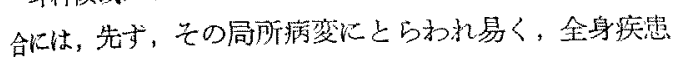
への配慮を意り腾らであるが，破傷風が数こ去少いが玫

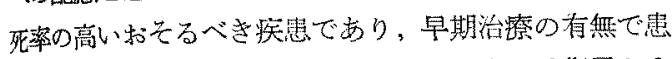

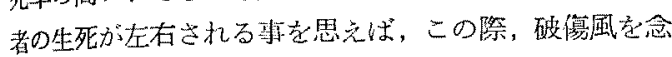

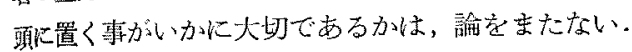

交颜化よると1913 年 M. Nicoll 结破傷風症状を伴つ

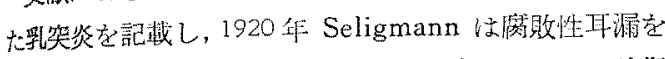

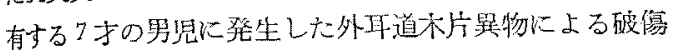
風報告し, 自ら耳性破富風の最初の例としている。 1927 年 Klestadt 及び Meseck (雨氏は別々に報告して

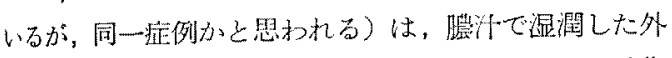
耳道の綿球から起つたと洘えられる5才半の幼览の破傷 風に際し，気管切閒及び中耳根本手術により一命在之り

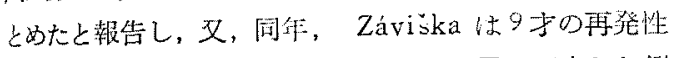

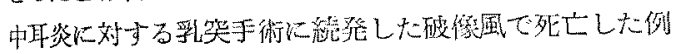
夲被告している。1929年 Borries, G.の䋓括的記戴に よると，乙れ等耳性破傷風は少いるのであり，外傷，表 皮脱落，及び中耳化膿症の二次的感染として発生し，㕲

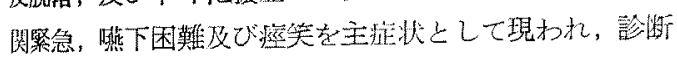
にあたり，屡々他宛患と混同さ机易い事，そして耳手術

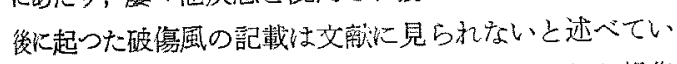
るが，1927年にZáviška が手術㣪に起つた症例を報告 していることは, 前記の如くである。

本邦では，耳疾患を原発部位としている耳性破㑥風に 阙する報告は少く、僅か飞菊地か㳓耳思肉上り侵入した 症例定，棍川が外耳道異物上り発生した例を，そして三 村方慢性穿扎性中耳炎患者の不潔なる外耳道タンポンよ り感染したと思われる例を記述し，又，三浦力慢性中耳 炎の経過中に外耳道から感染したと思礼る例を述べて

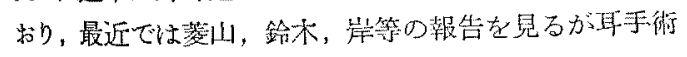

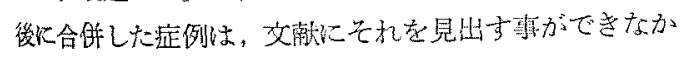
吃. 本症例の感染が, 果して手術によるものかどらか は明らかでないが, 再度に亘る箃重な消毒にも拘らず, 中耳腔内は消毒不充分になりがちであり，真珠缰や膿性

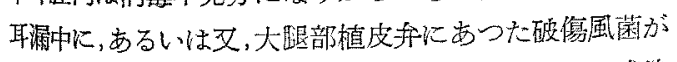
聋染したものか，西るいは皮成採取後の大眼部から感染 したむのか，ガーゼその他の手術器具の消毒が不完全だ つたのか，術前本人の気付かない時に受子た嚾かの外稘 より唚入せるものか，文は，舁曐が不潔な指やマッチ

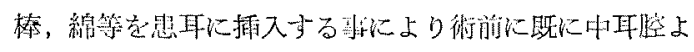
り感染していたものか，その感染経路を決定する東は困 難であるが，しかし，本症が，手術以外以外傷の既応在

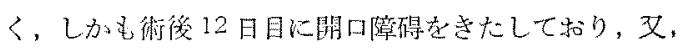
㜚野儿よる赫計的钼察に上れば，破傷風の潜伏期は，䅺

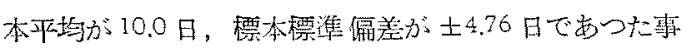
之照し合せると，手術時に感染したと考克るのが最も妥 当だと思秃れ，乙かも中耳腔を経たのであれば，術後1 週阔術創を閉鎖したこと〉，又，中耳内にあつた化澧菌 の增殖が墌気性菌である破傷風菌の增生を助長したと考 える事ができる、いずれにせよ，耳手㣠徯に合阙した破

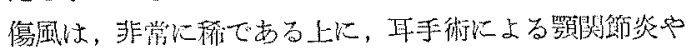

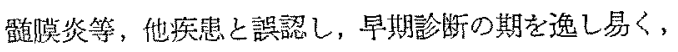
又 N.K. Apte $\not 3$ Post operative tetanus has been known to carry almost $100 \%$ mortality. と述へてい

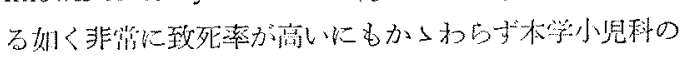

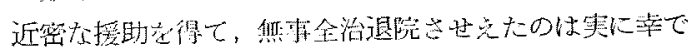
施ot.

\section{結語}

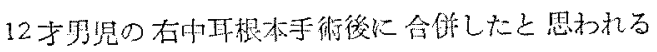

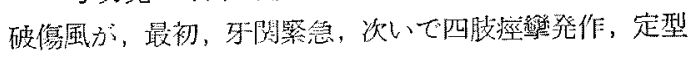

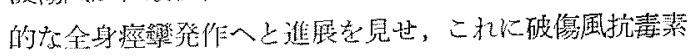

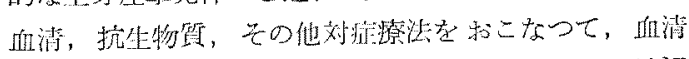

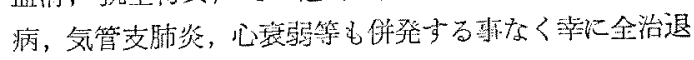
院させ劣た1例学報告した。

\section{文献}

1) 吉田治良。耳喉利, 3 替 4 号。

2) 和村荒夫：

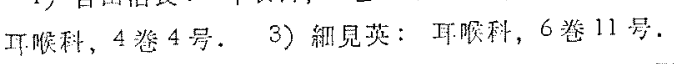

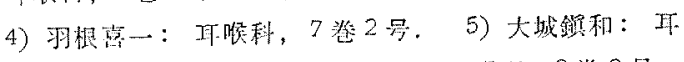

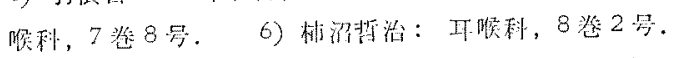

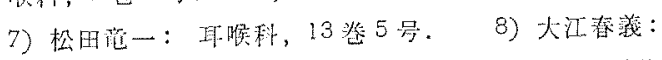

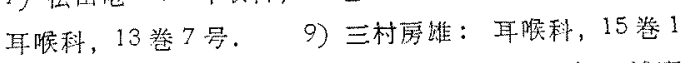

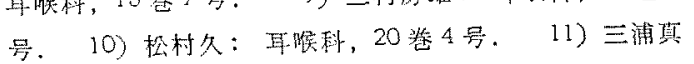

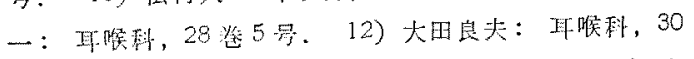
巻 10 号. 13) 内屿：評诶科，32巻4号，14）中

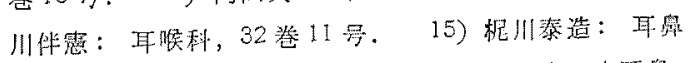

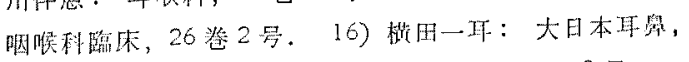

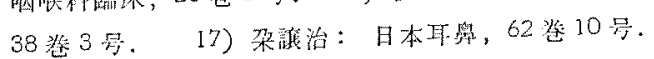

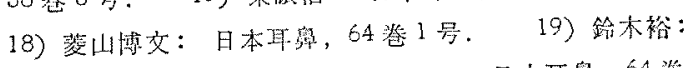

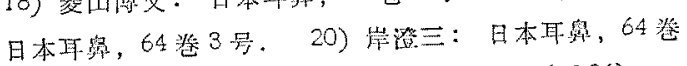

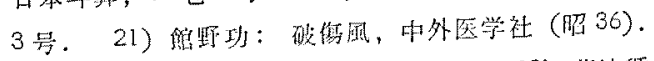
22) 沖中，资，坂本：
医术新明, 728 只.
内科洯叶卷。
23) 菞地证一:
24）森橲作：ク゚レンツゲビート 
巻 1,8荈. 25) 藤原治郎：千荣医專会誌, 大正四年. book of Medicine.

26) 後藤光治：診断と治療, 25 卷. 27) N.K. Apte:

The J. of Laryngol, and Otolog. Vol. LXXV, No. 8. 28) Mancioli, T.: Zbl. Ohrenheilk. '11. 29) M. Nicoll: Zbl. für Ohrenheilk. u. Rhino-Laryngol. '13. 30) Klestadt: Zbl. für H.N. u. O. Heilk. '27. 31) Meseck: Zbl, für H.N.u.O, Heilk. '27. 32) Zaviska: Zbl. für H.N.u.O. Heilk. '27. 33) Borries, G.: Zbl. für H.N.u.O. Heilk. '29. 34) Ferre, J.: Zbl. für H.N.u.O. Heilk. '53. 35) J. Lhotak: Z引l. für H.N.u.O. Heilk. 56.36$)$ Fan. coni: Lehrbuch d.Pädiatrie. 37) Cecil: Text-

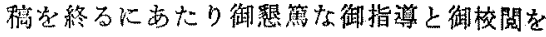
賜つた恩師高原淡大教授，はじめ，黑住静之助

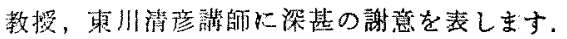
又, 御指導, 御援助を晹つた本学小児科浜本教

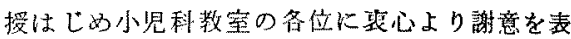
します

本詇交要旨性日本耳非咽喉科学会中国地方会 第 84 回例会に扣いて登窔した。

（原稿到着 $=$ 昭和 37.7 .13 日） 